\title{
CHROMOSOME CHARACTERIZATION OF TWO VARIETIES OF Mangifera indica $\mathrm{L}^{1}{ }^{1}$
}

\author{
NEIVA IZABEL PIEROZZI² \& CARLOS JORGE ROSSETTO
}

ABSTRACT - Chromosome studies were performed in two varieties of Mangifera indica L. (mango), 'IAC140 Espadona' and in its progenitor 'Espada Stahl'. Both varieties showed $2 \mathrm{n}=40$ chromosomes though the karyotype formulae were $8 \mathrm{~m}+10 \mathrm{sm}+2 \mathrm{sm}^{\mathrm{s}}$ for 'Stahl' and $7 \mathrm{~m}+11 \mathrm{sm}+2 \mathrm{sm}^{\mathrm{s}}$ for 'IAC-140'. The varieties showed moderate karyotype asymmetry which was estimated according to four different indices. Both varieties exhibited three chromosome pairs with silver impregnation after NOR-banding. The number of nucleoli within interphase cells varied from one, the commonest, to eight. The nucleolus persistent phenomenon was observed in more than $22 \%$ of metaphase cells of both varieties, seeing that in 'Stahl', up to two nucleoli were evidenced. This variety also showed one nucleolus in several anaphase cells. The studies were suitable for evidencing diversity at chromosomal level between these two varieties.

Key words: mango, mitotic chromosomes, persistent nucleolus, NOR-banding, $M$. indica.

\section{CARACTERIZAÇÃO CROMOSSÔMICA DE DUAS VARIEDADES DE MANGA}

RESUMO - Estudos cromossômicos foram efetuados em V. champinii, V. cinerea, V. girdiana, V. labrusca, $V$. rotundifolia, $V$. rupestris e $V$. vinifera com a finalidade de caracterização das espécies, usando dados de morfometria cromossômica e do bandamento NOR. Foi obtido um ideograma médio para cada espécie estudada. A fórmula cariotípica variou de $7 \mathrm{~m}+12 \mathrm{sm}$ a $9 \mathrm{~m}+11 \mathrm{sm}$. As espécies mostraram assimetria cariotípica moderada pelos índices de TF\% forma, Stebbins, Romero Zarco e Paszko. V. champinii e V. girdiana ficaram à parte das demais espécies pela representação gráfica de CVcl e CVci e também pelo dendrograma simplificado obtido pelo método de distância Euclidiana. O par cromossômico $\mathrm{n}^{\mathrm{o}} 3$ apresentou constrição secundária e segmento satélite nas espécies analisadas com Giemsa, podendo ser o mesmo evidenciado pelo bandamento NOR. Parece que o processo de especiação das espécies de Euvitis americanas estudadas envolveu mudanças discretas na morfometria dos cromossomos a qual se refletiu no índice de assimetria cromossômica.

Termos para indexação: cariótipo, bandamento NOR, cromossomos mitóticos, Vitis, Vitaceae.

\section{INTRODUCTION}

Members of the Anacardiaceae family are cultivated in many regions of the world due to their edible fruits and seeds, medicinal compounds, varnishes, resins and gums, valuable timber and also in regards to the beauty of some trees for garden ornamentation (BOMPARD, 2009). Several members, however, excel in horticultural importance, such as and mango (Mangifera indica L.) (MUKHERJEE; LITZ, 2009). Native to South Asia, it was introduced into Brazil by the Portuguese in the $16^{\text {th }}$ century. The first introductions comprised polyembrionic and fibrous fruits from Philippine races (SANTOS et al., 2008). The success of mango growth and production in Brazil is due to its favorable climate and soil. These factors contributed for the country to become the major mango producer in South America. Among the nearly 300 mango varieties growing in Brazil, some are cultivated for exporting to Europe and North America; others are for internal consumption, while others have been employed as rootstock (POMMER, 2008; PEROSA et al., 2009). The genus Mangifera comprises 69 species (BOMPARD, 2009) and based on some chromosome counts and meiotic analyses these are considered ancient allopolyploids. Chromosomal studies in Mangifera species initiated with Maheshwari (1934)

\footnotetext{
${ }^{1}$ Trabalho Sinfruit 050 - Simpósio Internacional de Fruticultura - Avanços na Fruticultura (17 a 21 Outubro) ${ }^{2}$ Pesquisadora. CPDP Recursos Genéticos Vegetais, Instituto Agronômico de Campinas (IAC).

Av. Barão de Itapura, 1481. Caixa Postal 28. Campinas-SP, Brasil. 13012-970. E-mail: pierozzi@iac.sp.gov.br

${ }^{3}$ Pesquisador. Pólo Noroeste Paulista/ APTA. Votuporanga-SP. E-mail: rossetto1939@gmail.com
} 
who reported an uncertain number as $2 \mathrm{n}=52-58$ chromosomes for $M$. indica. Later, Darlington and Ammal (1945) established the correct number as $2 n=40$. Mukherjee (1950 and 1957) enlarged the chromosome data studying different mango varieties and other Mangifera species.

The breeding program developed at the Instituto Agronômico de Campinas - IAC, has focused on resistance to diseases and pests, aiming at selecting resistant cultivars against mango wilt though allied with good fruit production (CARVALHO et al., 2004; ROSSETTO et al., 2006, for instance). As part of this program, two varieties of mango, 'IAC-140 Espadona' and its progenitor 'Espada Stahl', were characterized at cytological level using morphometric data.

\section{MATERIAL AND METHODS}

'IAC-140 Espadona' ('IAC-140') and its progenitor 'Espada Stahl' ('Stahl') varieties belong to IAC Fruit Collection at the Polo Regional de Votuporanga (Regional Station in the city of Votuporanga-PRV), where they have been growing. Seeds of these varieties were put in special plastic bags with soil to germinate at PRV. After some months they were transferred to a green house at IAC in the city of Campinas where they have been growing. Roots were collected, treated in a saturated solution of $p$-DB for $3 \mathrm{~h}$ at $16^{\circ} \mathrm{C}$, fixed in 3:1 (alcohol and acetic acid, respectively) solution and stored at $-20^{\circ} \mathrm{C}$ until chromosome analyses. Fixed root tips were softened in pectinase/cellulase for 1 hour at $36^{\circ} \mathrm{C}$. The slides were prepared by squashing the roots in $45 \%$ acetic acid solution. The coverslips were detached after a brtief bath in liquid nitrogen. It was applied the conventional 2\% Giemsa staining for 5 minutes to obtain chromosome measures and Ag-NOR banding according to Howell and Black (1980) for nucleolar organizer regions (NOR) localization and also for counting the nucleolus number in interphase cells. In order to investigate for the occurrence of persistent nucleolus phenomenon in metaphase and anaphase cells, ten slides were considered for each variety and all metaphase and anaphase cells were analyzed. It was calculated the mean values for the total haploid chromosome set (THCL), the longest (L) and the shortest (L) chromosome absolute $(\mu \mathrm{m})$ and relative $(\%)$ length, as well as the average chromosome length per haploid set ( $\chi$ chrom) and the ratio of the longest to shortest chromosomes (L/S). A karyotype formula was obtained for each variety and an average ideogram was drawn for each variety. The haploid chromosome set was represented in the ideograms. Mean values were also calculated for $\mathrm{TF} \%$ asymmetry index according to Huziwara (1956). The karyotypes were also analyzed by (a) Stebbins (1958) two-way system; (b) Romero Zarco (1986) intra (A1) and inter (A2) chromosomal system; and (c) AI index as proposed by Paszko (2006) which is composed by the chromosome length $(\mathrm{CVcl})$ coefficient of variation and by centromeric index (CVci) coefficient of variation. Statistical analyses of data were carried out by F-test.

\section{RESULTS AND DICUSSION}

The different chromosomal parameters such as morphometric data employed in comparative studies of cultivated plants with the same chromosome number have allowed for the characterization of cultivars and varieties. The studies have evidenced distinct karyotype formulae and ideograms which evidenced chromosomal diversity present among them (VIJAYAKUMAR; SUBRAMANIAN, 1985). In regards to mango, it was the first time that chromosome measures and comprehensive ideograms have been obtained for varieties developed in Brazil. Both 'Stahl' and 'IAC-140' var. studied showed a stable diploid number $2 \mathrm{n}=40$ (Figures $2 \mathrm{~A}$ and $2 \mathrm{~B}$ ), opposing to variations observed among some Indian varieties (MUKHERJEE, 1950). However, some differences concerning chromosome measures were observed between the varieties analyzed. M. indica var. 'Stahl' displayed higher mean values for THCL, average chromosome length, $\mathrm{L} / \mathrm{S}$ ratio, as well as for the longest and the shortest chromosomes of the genome (Table 1), for $\mathrm{TF} \%, \mathrm{~A} 2$, $\mathrm{CVcl}$ and for AI (Table 2); nevertheless these values were not significantly different when compared to those of var. 'IAC-140', except for the shortest chromosome and $\mathrm{L} / \mathrm{S}$ ratio where the difference was significant.

Concerning karyotype formula, 'Stahl' showed $8 \mathrm{~m}+10 \mathrm{sm}+2 \mathrm{sm}^{\mathrm{s}}$, whereas 'IAC-140' $7 \mathrm{~m}$ $+11 \mathrm{sm}+2 \mathrm{sm}^{\mathrm{s}}$. 'Stahl' was classified as ' $1 \mathrm{~A}$ ' while 'IAC-140' as '1B' according to Stebbins concept. Inter chromosomal asymmetry value (A2) was higher for 'Stahl' while intra chromosomal asymmetry value (A1) was higher for 'IAC-140'. 'Stahl' also showed a higher value for $\mathrm{CVcl}$ (Table 2). Both graphic representations of $\mathrm{A} 1$ and $\mathrm{A} 2$ asymmetry and of $\mathrm{CVcl}$ and $\mathrm{CV}$ ci indices combined to Stebbins classification were suitable for separation of varieties (Figure 1). The varieties displayed two chromosome pairs with secondary constriction (SC) associated with a satellite segment (Sat) visible in metaphase after 
Giemsa staining and three pairs of chromosomes with Ag-NOR banding (Figures 2D and 2E) seeing that one pair showed a preeminent silver impregnation, followed by one other with a smaller impregnation and by another with a small dot of impregnation. This difference observed between the numbers of chromosome pairs visualized by Giemsa staining (two) and by Ag-NOR banding (three) in both varieties analyzed may be attributed to the small size of the secondary constriction of one of the AgNOR banded chromosome pairs, which hindered its visualization by conventional staining methodology. In M. caesia Mukherjee (1957) three chromosome pairs were reported with satellite and secondary constriction, but among 24 varieties of $M$. indica the number of chromosomes carrying secondary constriction and satellite segment was higher and varied from 4 to 8 pairs (MUKHERJEE, 1950) which may be seen as an increase in NOR numbers due to unequal interchanges between NOR bearing chromosomes and chromosomes without NOR regions.

Nucleolus number visualized at interphase cells after Ag-NOR banding varied from one in large size, which was the prevalent, to eight in small size (Figure 2C). These variations in the NOR sizes have also been observed in another variety by Yonemori et al. (2004) after in situ hybridization with probes for 45S rDNA genes. It is broadly accepted that silver NOR positive chromosome signals correspond to the locations of active rRNA genes and the size and intensity of the silver-stained sites are related to their transcriptional activity (GOLCZYK; JOACHIMIAK, 2003). In such cases, the differences observed in the size of NOR sites after silver impregnation (NOR band) may reflect differences in their activity and/ or in rDNA sequence amounts.

The varieties differed statistically according to the percentage of interphase cells with two, three and four nucleoli. The percentage of cells with one nucleolus varied from $82.47 \%$ to $84.23 \%$ and those with two nucleoli varied from $12.31 \%$ to $15.85 \%$. The percentage values for any other amount of nucleolus (three to eight) were smaller than these (Table 3). Eight nucleoli were only seen in several cells of 'Stahl'. The discrepancy between the number of chromosome pairs (three) and the maximum number of nucleoli (eight) in interphase cells after Ag-NOR banding in 'Stahl' may be due to: (a) the existence of a chromosome pair carrying a very small NOR site, which was not detected neither by conventional staining nor by silver impregnation; (b) a low level of silver impregnation in this NOR pair, which was not visualized; or (c) a low rDNA transcriptional activity which made it difficult or hindered the silver impregnation. The nucleolus has long been associated with ribosome biogenesis and as a dynamic structure, it often undergoes a cycle of disappearance and reconstitution (MA; PEDERSON, 2008).

Persistent nucleolus phenomenon was not observed in some metaphase cells of both varieties and only in anaphase cells of 'Stahl' progenitor (Figure $1 \mathrm{~F})$. The phenomenon of nucleolar persistence has been observed in several angiosperms such as in Cucurbita maxima and C. pepo (FREW; BOWEN, 1929) and in 21 legume species (MURUGESAN et al., 2001), for instance. It can also be induced by chemical mutagens as MMS or DMS, for instance, in rice (REDDI; REDDI, 1985), or by gamma ray irradiation in grass pea (KUMAR; TRIPATHI, 2007). It was also observed in tree populations growing in an industrial region with the emission of air pollutants and in some cases, strengthened by environmental atypical changes, such as drought (VOSTRIKOVA; BUTORINA, 2006, SEDEL'NIKOVA; PIMENOV, 2007). The causes for the persistence are not clear and the regulation of nucleolus assembly and disassembly is controlled by many proteins in a complex cascade of events (EMMOTT; HISCOX 2009); the understanding of the persistence of nucleolus phenomenon during mitosis calls for more studies at the molecular level. In mango, it is the first time that this phenomenon has been reported. Considering that only two mango varieties were analyzed it is not possible to assert that the persistence of the nucleolus is a peculiar characteristic of varieties developed in Brazil or a feature of old or fibrous varieties as 'Espada', for instance. Though the causes of this persistence in mango mitosis is not clear, it was assumed to be associated with (a) the allopolyploid nature of mango; (b) disturbance in the biosynthesis of some nucleolar component which stimulated the persistence; (c) disturbance in some pathway related to nucleolar disassembly; (d) failure in the phosphorilation machinery at RNA pol I, as mentioned before; and (e) requirement of some nucleolar proteins to the mango cell cycle progression compelling its persistence. Nevertheless, no very satisfactory or conclusive explanation for the occurrence of this persistence has yet been given.

Even though Anacardiaceae is considered a medium size family, comprising 73 genera only $33 \%$ of them have some chromosome information. The present data also enriched information concerning mango species and varieties, mainly about Brazilian ones, since out of thousands of $M$. indica varieties, which have been cultivated around the pan tropical 
world regions, less than $5 \%$ of them have been

citomolecular approaches as observed by Iyer and characterized by chromosome number or by

Schnell (2009).

TABLE 1 - Mean values with sd for total haploid chromosome length (THCL), average chromosome length ( $\chi$ chrom), the longest (L) and the shortest (S) chromosome length and the ratio of the longest to the shortest chromosome (L/S) for M. indica vars. 'Stahl' and 'IAC-140'

\begin{tabular}{lccccc}
\hline Var. & TCHL $(\mu \mathbf{m})$ & $\mathbf{L}(\boldsymbol{\mu m})$ & $\mathbf{S}(\boldsymbol{\mu m})$ & $\chi \mathbf{c r o m}$ & $\mathbf{L} / \mathbf{S}$ \\
\hline Stahl & $28.08 \pm 2.45^{\mathrm{a}}$ & $1.83 \pm 0.09^{\mathrm{a}}$ & $1.00 \pm 0.08^{\mathrm{a}}$ & $1.40 \pm 0.12^{\mathrm{a}}$ & $1.76 \pm 0.21^{\mathrm{a}}$ \\
IAC 140 & $24.37 \pm 1.52^{\mathrm{a}}$ & $1.81 \pm 0.15^{\mathrm{a}}$ & $0.87 \pm 0.07^{\mathrm{b}}$ & $1.22 \pm 0.08^{\mathrm{a}}$ & $2.10 \pm 0.22^{\mathrm{b}}$ \\
\hline
\end{tabular}

Means followed by the same letter $=$ differences were not significant at the level of $1 \%$ after $\mathrm{F}$ test.

Means followed by different letters $=$ differences were significant at the level of $1 \%$ after $\mathrm{F}$ test.

TABLE 2 - Karyotype formula (KF) and asymmetry indices of TF\%, Stebbins (Stebb), A1 and A2, CVcl and CVci with the product AI, for M. indica vars. 'Stahl' and 'IAC-140'

\begin{tabular}{lcccccccc}
\hline & KF & TF\% & Stebb & A1 & A2 & CVcl & CVci & AI \\
\hline Stahl & $8 \mathrm{~m}+10 \mathrm{sm}+2 \mathrm{sm}^{\mathrm{s}}$ & $39.25 \pm 1.28^{\mathrm{a}}$ & $1 \mathrm{~A}$ & 0.34 & 0.09 & 12.27 & 9.12 & 1.12 \\
IAC-140 & $7 \mathrm{~m}+11 \mathrm{sm}+2 \mathrm{sm}^{\mathrm{s}}$ & $37.08 \pm 1.72^{\mathrm{a}}$ & $1 \mathrm{~B}$ & 0.39 & 0.08 & 8.57 & 9.24 & 0.79 \\
\hline
\end{tabular}

Means followed by the same letter $=$ differences were not significant at the level of $1 \%$ after $\mathrm{F}$ test.

Means followed by different letters $=$ differences were significant at the level of $1 \%$ after $\mathrm{F}$ test.

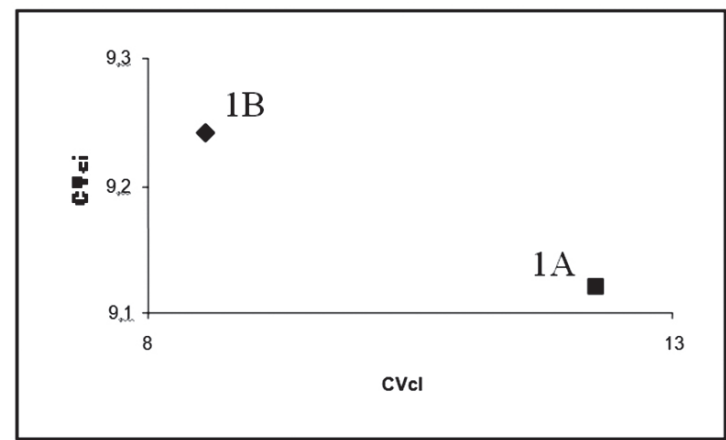

FIGURE 1 - Paszko's Scattered diagram showing karyotype asymmetry associated to Stebbins classification ('Stahl=1A; 'IAC 140’=1B).

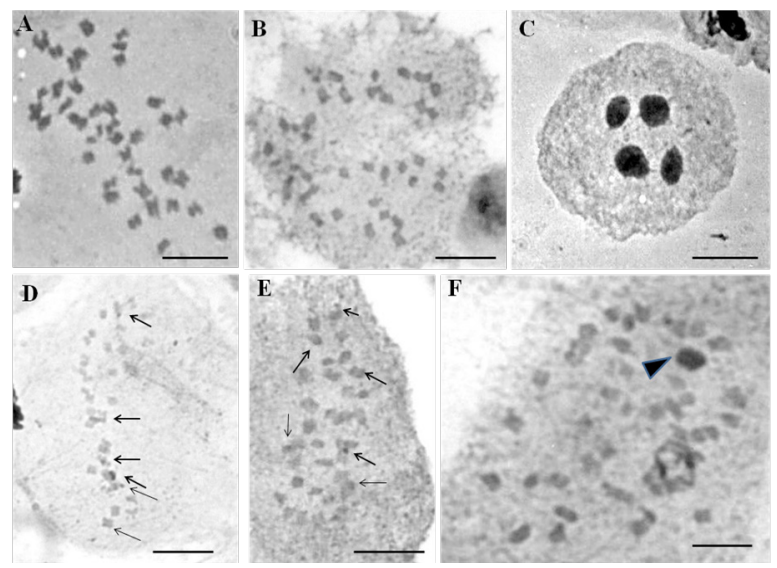

FIGURE 2 - Mitotic chromosomes of M. indica staining with Giemsa (A -'Stahl'; B -'IAC-140') and AgNOR (C and D, Stahl; $\mathbf{E}$ and F, IAC-140); bar $=5 \mu \mathrm{m}$. C - Four nucleoli in interphase cell of 'Stahl' (bar $=20 \mu \mathrm{m})$. Arrow = satellite chromosomes; arrow head $=$ persistent nucleolus. 
TABLE - 3 Percentage mean values of interphase cells of $M$. indica vars. 'Stahl' and 'IAC-140' with different nucleoli numbers (from $1 \mathrm{nu}$ to $8 \mathrm{nu}$ )

\begin{tabular}{lccccccc}
\hline & 1nu & 2nu & 3nu & 4nu & 5nu & 6nu & 8nu \\
\hline Stahl & $84.23 \pm 4.06^{\mathrm{a}}$ & $12.31 \pm 3.47^{\mathrm{a}}$ & $2.79 \pm 1.05^{\mathrm{a}}$ & $0.44 \pm 0.39^{\mathrm{a}}$ & $0.01 \pm 0.03^{\mathrm{a}}$ & $0.15 \pm 0.18^{\mathrm{a}}$ & $0.06 \pm 0.16^{\mathrm{a}}$ \\
IAC-140 & $82.4 \pm 1.84^{\mathrm{a}}$ & $15.85 \pm 1.90^{\mathrm{b}}$ & $1.49 \pm 0.92^{\mathrm{b}}$ & $0.14 \pm 0.20^{\mathrm{b}}$ & $0.02 \pm 0.06^{\mathrm{a}}$ & $0.04 \pm 0.12^{\mathrm{a}}$ & $0.00 \pm 0.00^{\mathrm{a}}$ \\
\hline
\end{tabular}

Means followed by the same letter $=$ differences were not significant at the level of $1 \%$ after $\mathrm{F}$ test.

Means followed by different letters $=$ differences were significant at the level of $1 \%$ after $\mathrm{F}$ test.

\section{CONCLUSION}

The chromosomal parameters employed in the present research were valuable and allowed for mango varieties characterization and were also appropriate to evidence diversity at chromosomal level between these two close varieties, 'Stahl' and 'IAC-140'. They also enriched information concerning mango species and varieties, mainly about Brazilian ones.

\section{REFERENCES}

BOMPARD, J.M. Taxonomy and systemactics. In: LITZ, R.E. (Ed.). Mango: botany production and uses. Wallingford: CABI, 2009. p.19-41.

CARVALHO，C.R.L.; ROSSETTO，C.J.; MANTOVANI, D.M.B.; MORGANO, M.A.; CASTRO, J.V.; BORTOLETTO, N. Avaliação de cultivares de mangueira selecionadas pelo Instituto Agronômico de Campinas comparadas a outras de importância comercial. Revista Brasileira de Fruticultura, Jaboticabal, v.26, n.1, p. 264-271, 2004.

DARLINGTON, C.D.; AMMAL, E.K.J. Chromosome atlas of cultivated plants. London: G. Allen \& Unwin, 1945. 397p.

EMMOTT, E.; HISCOX, J.A. Nucleolar targeting: the hub of matter. European Molecular Biology Organization Reports, London, v. 10, n.3, p.231$238,2009$.

FREW, P.E.; BOWEN, R.H. Nucleolar behavior in the mitosis of plant cells. Quarterly Journal of Microscopy Science, Chicago, v.73, n.2, p.197-212, 1929.

GOLCZYK, H.; JOACHIMIAK, A. NORs in Rhoeo (Commelinaceae) revisited. Caryologia, Firenze,v.56, n.1, p.31-35, 2003.
HOWELL, W.M.; BLACK, D.A. Controlled silverstaining of nucleolus organized regions with a protective colloidal developer: a 1-step method. Experientia, Basel, v.36, n.9, p.1014-1015, 1980.

HUZIWARA, Y. Karyotype analysis in some genera of Compositae I. Karyotype of Japanese Eupatorium. Cytologia, Tokyo, v.21, n.2, p.114-123, 1956.

IYER, C.P.A.; SCHNELL, R.J. Breeding and genetics. In: LITZ, R.E. (Ed.). Mango: botany production and uses. Wallingford: CABI, 2009. p.67-96.

KUMAR, G.; TRIPATHI, R. Anomalous nucleolar and chromosomal organization in induced phenodeviants of grasspea. Cytologia, Tokyo, v.72, n.3, p. 345-350, 2007

MA, H. ; PEDERSON, T. Nucleostemin: a multiplex regulator of cell-cycle progression. Trends in Cell Biology, Cambridge, v.18, n.12: 575-579, 2008.

MAHESHWARI, P. The Indian mango. Current Scince, Bangalore,v.3, n.1, p.97-98, 1934.

MUKHERJEE, S.K. Cytological investigation of the mango (Mangifera indica L.) and the allied Indian species. Proceedings of National Institute of Science of India, New Delhi, v.16, n.1, p.287303, 1950.

MUKHERJEE, S.K. Cytology of some Malayan species of Mangifera. Cytologia, Tokyo, v.22, n.2, p.239-241, 1957.

MUKHERJEE, S.K.; LITZ, R.E. Introduction: botany and importance. In: LITZ, R.E. (Ed.). Mango: botany production and uses. Wallingford: CABI, 2009. p.1-18.

MURUGESAN, R.; CHANDRA, N.; SANTHIYA, S.T.; GOPINATH, P.M.; MARIMUTHU, K.M Nucleolar behavior in a few legumes. Caryologia, Firenze, v. 54, n.1, p. 17-21, 2001. 
PASZKO, B. A critical review and a new proposal of karyotype asymmetry indices. Plant Systematics and Evolution, Vienna, v.258, n.1, p. 39-48, 2006.

PEROSA, J.M.Y.; SILVA, C.S.; ARNALDI, C.R. Avaliação das perdas de manga (Mangifera indica L.) no mercado varejista da cidade de Botucatu. Revista Brasileira de Fruticultura, Jaboticabal,v.31, n.3, p.732-738, 2009.

POMMER, C.V. The impact of breeding on fruit production in warm climates of Brazil. Revista Brasileira de Fruticultura, Jaboticabal, v.31, n.2, p. 612-634, 2009.

REDDI, T.V.V.S.; REDDI, V.R. Cytogenetical effects of chemical mutagens in rice. Cytologia, Tokyo, v. 50, n.3, p.499-505, 1985.

ROMERO ZARCO, C. A new method for estimating karyotype asymmetry. Taxon,Vienna, v.35, n.3, p.526-530, 1986.

ROSSETTO, C.J.; BORTOLETTO, N.; WALDER, J.M.M.; MASTRANGELO, T.A.; CARVALHO, C.R.L.; CASTRO, J.V.; PINTO, A.C.Q.; CORTELAZZO, A.L. Mango resistance to fruit flies. II. Resistance of the Alfa cultivar. In: INTERNATIONAL SYMPOSIUM OF FRUIT FLIES, 7., 2006. Proceedings... Salvador: Biof. Moscamed, 2006. p.171-174.
SANTOS, C.A.F.; LIMA NETO, F.P.; RODRIGUES, M.A.; COSTA, J.G. Similaridade genética de acessos de mangueira de diferentes origens geográficas avaliadas por marcadores AFLP. Revista Brasileira de Fruticultura, Jaboticabal, v. 30, n.3, p.736-740, 2008.

SEDEL'NIKOVA, T.S.; PIMENOV, A.V. Chromosomal mutation in Siberian larch (Larix sibirica Ledeb.) on Taimyr Peninsula. Biology Bulletim, Nauk, v.34, n.2, p.198-201,2007.

STEBBINS, G.L. Longevity, habitat, and release of genetic variability in the higher plants. Cold Spring Harbor Symposia on Quantitative Biology, New York, v.23, n.1, p.365-378, 1958.

VIJAYAKUMAR, N.; SUBRAMANIAN, D. Cytotaxonomical studies in South Indian Myrtaceae. Cytologia, Tokyo, v.50, n.3, p.513-520, 1985.

VOSTRIKOVA, T.V.; BUTORINA, A.K. Cytogenetic responses of birch to stress factors. Biology Bulletim, Nauk, v.33, n.2, p.185-190, 2006.

YONEMORI, K.; NISHIYAMA, K.; CHOI, Y.A. Physical mapping of $5 \mathrm{~S}$ and $45 \mathrm{~S}$ rDNAs by fluorescent in situ hybridization in mango (Mangifera indica L.), In: INTERNATIONAL SYMPOSIUM OF TROPICAL AND SUBTROPICAL FRUITS, 3., 2004. Proceedings... Fortaleza: Embrapa Agroindústria, 2004. p.889. 